\title{
Regulatory Regimes of Islamic Banking in ASEAN Economic Community (AEC): A Uniting Force in the Industry of the Region
}

\author{
Dr. Abdurrahman Raden Aji Haqqi \\ Faculty of Shariah and Law \\ Sultan Sharif Ali Islamic University (UNISSA) \\ Jalan Pasar Gadong
}

\begin{abstract}
ASEAN Economic Integration has provided the platform for ASEAN countries to restructure their finance sectors and move forward to better cooperation among economies. In banking, the ASEAN market's increasingly free flow of products and services will open up growth opportunities in both retail and wholesale. Brunei with its Islamic Banking Order 2008 expected to gain a 55\%-60\% share of all banking assets in the country; in Indonesia, after a developmental plan namely the Blueprint of Islamic Banking Development, the country's commitment was followed by the enactment of the National Act No.21/2008, ratified in July 2008, which provides an adequate legal foundation for the development of Islamic banking; while in Malaysia, to further improve the banking legislation of the industry, It has enacted a new comprehensive Act, the Islamic Financial Services Act that has come into effect in June 2013; The Philippines' central bank, on the other hand, is pushing several important initiatives in legislation, regulation and taxation to promote Islamic banking in the country; while in Singapore Islamic banking institutions are regulated through a number of amendments to existing regulations and several related guidelines; finally, in Thailand today there is only one Islamic bank operating in the country: the state-owned Islamic Bank of Thailand, established in 2002 under its own banking regulation. How does Islamic banking industry participate and contribute in this market? This paper attempts at discussing regulatory regime of Islamic banking in ASEAN country after the implementation of AEC in the end of 2015.
\end{abstract}

Keywords: regulatory regime - Islamic banking - aec - uniting force

\section{INTRODUCTION}

Islamic financial system has experienced remarkable growth and transformation, demonstrating its potential as a competitive form of financial intermediation in the recent decade. The modern Islamic financial system has risen to become a trillion dollar industry. Islamic finance has grown far from its domestic root to emerge as one of the fastest growing financial markets in the international field.

The regulatory regimes for Islamic banking institutions in ASEAN countries are formulated in the image of conventional banking system. Some countries lack proper legal framework with some notable issues includes the lack of a dedicated Islamic banking law with few laws relating to corporate governance. However, most of the countries follow regulation of their domicile and International Accounting Standards (IAS) with some countries are adopting Islamic accounting standards.

Hence, at present, Islamic banks and financial institutions operate under three different regulatory regimes:

1) Self-regulation through constitutional limitation; 
2) Private regulation through governmental private legislation;

3) Public regulation through governmental national legislation. ${ }^{1}$

ASEAN countries before and after the implementation of ASEAN Economic Community (AEC) last year are implementing legislative and legal reforms to support the development of the Islamic banking industry. There have been many new year-to-date regulatory developments in Islamic finance, which have only served to cement the increasing popularity of this new assets class. With rapid developments being made across the world, it can be inferred that the growth in Islamic finance has been universal and it has been gaining ground at national, regional and international levels.

It is the task of regulators of Islamic banking industry because of various difficulties to harmonize Islamic banking practices, facilitating cluster or regional regulations and practices to make the priority towards greater harmonization of the Islamic banking system.

The main purpose of this paper is to highlight the regulatory framework, key regulatory institutions and current legal and regulatory issues of Islamic banking in ASEAN countries and to evaluate its current status of the regulatory framework by concentrating the discussion on the uniting force in the industry.

\section{THE REGULATORY FRAMEWORK}

The Islamic financial services industry (IFSI), with its proposition of inclusiveness, has rapidly progressed across the globe, embracing not only Muslim-majority economies but also other emerging markets and advanced economies. The development of this industry encompasses not only an increase in the business volume and number of institutions offering Islamic financial services (IIFS), but also an enhanced variety of the products and services offered, improved legal and regulatory infrastructure, and new initiatives for international cooperation. Accordingly, the IFSI has gained significant market share, and now constitutes an important building block of the financial systems in many jurisdictions. This development and growth has raised a number of challenges for the resilience and stability of financial systems, and for the protection of their users.

In view of the above, the Islamic Financial Services Board (IFSB) Council, in its 21st Meeting held on 12 December 2012 at Islamic Development Bank headquarters in Jeddah, Kingdom of Saudi Arabia, approved the preparation of a set of IFSB Core Principles for Islamic Finance Regulation (hereinafter referred to as "CPIFR").

The main objective of the CPIFR is to provide a set of core principles for the regulation and supervision of the IFSI, taking into consideration the specificities of the IIFS in the banking segment and the lessons learned from the financial crisis, and complementing the existing international standards, principally the BCBS's Core Principles for Effective Banking Supervision (Basel Core Principles, or BCPs). In particular, the objectives of the CPIFR include:

a) providing a minimum international standard for sound regulatory and supervisory practices for the effective supervision of the IIFS;

b) protecting consumers and other stakeholders by ensuring that the claim to Sharìah compliance made explicitly or implicitly by any IIFS is soundly based;

1 Dr. Tariq Hassan, "Islamic Banking: The Need for Uniform Regulation”, Journal of Islamic Banking and Finance, Vol: 8, Issue:2, April-June 1991, 15-30. 
c) safeguarding systemic stability by preserving the linkages between the financial sector and the real economic sector1 which underlie Islamic finance; and

d) ensuring that IIFS act in accordance with their fiduciary responsibilities in all their operations, especially in regard to investment account holders (i.e. investors in profitsharing investment accounts [PSIAs]). ${ }^{2}$

Ensuring an adequate alignment of the regulatory framework with the guidelines of standard setters is key to address the main risks inherent in Islamic Banks operations. The authorities should also ensure that the regulatory framework for Islamic banks puts them at a level playing field with CBs. In most countries where IBs are present, the conceptual regulatory framework of the Basel Committee on Banking Supervision (BCBS) is the default framework. However, several jurisdictions complement it by the standards of the Islamic Financial Services Board (IFSB) and the Accounting and Auditing Organization for Islamic Financial Institutions (AAOIFI) to give effect to Shariah Law compliance. In particular, about 65 percent of the jurisdictions that allow Islamic Banks have tailored their conventional banking regulations for Islamic Banks activities. ${ }^{3}$ There are several dimensions of the regulatory framework that need to take into account the special characteristics of Islamic Banks. ${ }^{4}$ These dimensions are licensing, ${ }^{5}$ liquidity, ${ }^{6}$ capital, ${ }^{7}$ transparency and disclosure, ${ }^{8}$ and deposit insurance and bank resolution. ${ }^{9}$

Here are some regulatory frameworks of Islamic banking in ASEAN countries:

2 Islamic Financial Service Board. (2015). Core Principles For Islamic Finance Regulation (BANKING SEGMENT)(CPIFR, Kuala Lumpur: IFSB. P. 1-2.

3 Song, Inwon and Carel Oosthuizen, 2014, "Islamic Banking Regulation and Supervision- Survey Results and Challenges," IMF Working paper No. 14/220, (Washington: International Monetary Fund).

${ }^{4}$ Alejandro López Mejía, Suliman Aljabrin, Rachid Awad, Mohamed Norat, and Inwon Song, "Regulation and Supervision of Islamic Banks", IMF Working Paper No WP/14/219, (Washington: International Monetary Fund, 2014.

${ }^{5}$ Several elements of an appropriate licensing process are common to IBs and CBs, but certain modifications are needed to take into account the nature of IB. However, few jurisdictions (if any) apply fit and proper requirements to SSB members and to staff in IBs in charge of Shariah compliance. Developing and implementing these fit and proper requirements would be important. In the case of licensing an Islamic baking window, the CB that applies for it should ensure the effective segregation of funds in each window (conventional and Islamic), including through appropriate internal systems and reporting processes.

${ }^{6}$ The liquidity risks faced by IBs can generally be addressed by a combination of BCBS and IFSB liquidity rules. That said, as is the case in many emerging and developing economies, implementation of key elements of the newly internationally agreed liquidity framework (i.e., the liquidity coverage ratio (LCR), and the net stable funding ratio (NSFR) is likely to pose significant challenges to jurisdictions with strong IB presence. Enhancing the regulatory framework on liquidity will need to effectively tackle the availability of short term funds. Jurisdictions with stronger IB presence have made some progress, but many challenges remain

${ }^{7}$ On capital, it is also key that jurisdictions where IBs are present focus on implementing the BCBS-IFSB framework. While complying with the Basel Core Principles for Effective Bank Supervision (BCP) should be a priority for all countries, most jurisdictions would also benefit from a progressive movement towards implementing elements of Basel II and III.

${ }^{8}$ Improving disclosure is key to provide the supervisory authorities and the public with a better understanding of banks' strategies and relevant risks. Despite the importance of a transparent accounting and financial reporting framework tailored to IB, its formal incorporation into legal and regulatory frameworks has been progressing at a slow pace.

${ }^{9}$ Effectively dealing with the issue of deposit insurance is key to promote the stability of IBs. In the case of IB, the main challenge for deposit insurance is to identify its scope, including whether it covers profit sharing investment accounts (IFSB, 2013). 


\section{Brunei Darussalam}

Brunei Darussalam is widely known for the sovereignty of the monarchy and the in-depth practices of Islamic principles and teachings. The Sultanate incorporates Islam in its people's daily lives which is apparent from various angles, such as the food industry, hospitality industry, as well as the financial services industry. ${ }^{10}$

Among legal frameworks for Islamic financial institutions in Brunei Darussalam are based on the following acts and orders of authority: ${ }^{11}$

- Perbadanan Tabung Amanah Islam Brunei Act (TAIB), 1991 (Chapter 163)

- Islamic Banking Act (IBA), 1992 (Chapter 168) - repeal by Islamic Banking Order (IBO), 2008

- Finance Companies Act (Amendment) Order (FCA), 2006

- Shari'ah Financial Supervisory Board Order (SFSB), 2006

- Takaful Order (TO), 2008

- Securities Market Order (SMO), 2013

A well-functioning financial system allows the transfer of money between savers and borrowers. Its importance is often taken for granted until it is either gone or performing poorly, like consumers having to go around asking strangers for money so they could buy a car because there aren't any banks. Autoriti Monetari Brunei Darussalam or AMBD exists to ensure that the financial system is continuously functioning properly.

AMBD was established on January 1, 2011 and acts as the central bank of Brunei Darussalam. It carries out several vital roles - it regulates and supervises financial institutions, formulates and implements monetary policies, and manages the Brunei Dollar currency and the central bank's international reserves that allow for seamless convertibility of Brunei Dollars into foreign currencies.

In preserving the purity of Islamic financial products and the operations of the Islamic financial institutions, Brunei Darussalam implements a rigorous two-tier Syariah governance framework, comprising of a Syariah Financial Supervisory Board (SFSB) at the national level, and Syariah Advisory Board (SAB) at the industry level. The board members are renowned and prominent Islamic scholars with diverse experience and background including Syariah, legal, economics and finance.

To ensure continuity and efficiency of the Syariah bodies, AMBD is highly supportive of cultivating the local talent for the purpose of expanding the pool of Islamic scholars so that there is an orderly succession planning. To this end, the Centre for Islamic Banking, Finance and Management (CIBFM) has produced junior Islamic scholars under the Fiqh Muamalat Professional Programme (FMPP), which has attracted participation both from Muslims and non-Muslims alike. Furthermore, our higher education institutions such as the Universiti Brunei Darussalam (UBD) and Universiti Islam Sultan Sharif Ali (UNISSA) offer courses up to PhD level in Islamic finance.

\footnotetext{
10 See: Abdul 'Ali, Muhd Jamil Abas bin, Swee, Tan Thiam \& Chin, Lee Yun. (2014). "Brunei: Islamic Banking and Finanace" in The Islamic Finance Handbook: A Practitioner's Guide to the Global Markets. (Singapore: John Wiley \& Sons Singapore Pte. Ltd, 2014)

11 See: Haqqi, Abdurrahman Raden Aji. "Regulatory Regime in Enhancing the Implementation of Islamic Economics Relating Financial Sectors in Brunei Darussalam", paper presented at $4^{\text {th }}$ ASEAN International Conference on Islamic Finance (4th AICIF), IIUM Institute of Islamic Banking and Finance, 6-8 December 2016, Equatorial Hotel, Melaka, Malaysia.
} 
To support the development of Islamic finance in Brunei Darussalam, AMBD is encouraging academics and professionals to conduct more research on the areas of product structure, harmonisation of Islamic concepts, regulation and governance. As a result, we hope to see more product innovation to cater to the demands of consumers in the global changing environment and at the same time, to reach a level playing field with the conventional financial industry. ${ }^{12}$

\section{Indonesia}

Bank Indonesia (BI) is no longer the banking supervisory authority following the Financial Services Authority (OJK) assuming capital market and banking supervisory functions. IFIs are also governed and bound by any direction and instruction of the Financial Services Authority. The Financial Services Authority in Indonesia is expected to boost market confidence and to promote financial stability and good governance as well as to enhance consumer protection. ${ }^{13}$

In terms of legislation, there is no significant reform on the regulatory framework of Islamic finance in Indonesia. Indonesia is still relying on the Act No 21 of 2008 Islamic Banking Law which provides legal foundation for the development of Islamic finance. In terms of guidelines and directives, no new guidelines were issued in 2013 by either Bank Indonesia or the Financial Services Authority, which relates specifically to Islamic banks. IFIs in Indonesia are governed by the following directives:

- Bank Indonesia Regulation Number 13/23/ PBI/2011 Concerning The Implementation Of Risk Management In Islamic Commercial Banks and Islamic Business Units;

- Bank Indonesia Regulation Number 13/14/ PBI/2011 Concerning Asset Quality Rating for Islamic Rural Banks.

- Bank Indonesia Regulation Number 13/23/ PBI/2011 Concerning The Implementation Of Risk Management In Islamic Commercial Banks and Islamic Business Units.

Under the Indonesia Banking Architecture Guidelines there are two major developmental plans namely the Blueprint of Islamic Banking Development and the Grand Strategy of Islamic Banking Market Development. ${ }^{14}$

Act No 21 of 2008 is the primarily legislation which provided comprehensive regulatory framework for Shariah banking in Indonesia. It was drafted in order to actively develop the Islamic banking sphere and provided for licensing as well as prohibitions for Shariah banking operations. $^{15}$

The Indonesian Central Bank (Bank Indonesia) issued regulations in 2009 and subsequently amended in 2013, relaxed ownership restrictions allowing foreign share ownership of up to $99 \%$ of the paid up capital of Islamic Banks.

The OJK now has sole regulatory oversight of the Islamic banking sector and has made great strides since taking over from Bank Indonesia in 2014.

\footnotetext{
12 Awang Yusof bin Haji Abd Rahman, "Islamic Finance - Steps for a Better Tomorrow", International Finance and Banking Society (IFABS) 2016 Brunei Conference, 16 August 2016, Brunei Darussalam.

13 See: Rifki Ismal, "Indonesia: The Resilience and Prospects of Islamic Banking" in The Islamic Finance Handbook: A Practitioner's Guide to the Global Markets. (Singapore: John Wiley \& Sons Singapore Pte. Ltd, 2014)

14 See: http://isfire.net/the-state-of-islamic-finance-in-malaysia-and-indonesia/

${ }^{15}$ Adil Hussain and Neil Williams, "Islamic Finance in Indonesia", Clyde and Co, June 15, 2016. See also: http://www.islamicfinancenews.com/newsletter-issue/volume11issue10
} 
New rules were issued by the OJK November 2014 to promote and regulate Islamic finance development in Indonesia. These rules include:

- Fully fledged Islamic banks are subject to increased capital adequacy measures based on their risk profile, with the capital adequacy requirement being raised from $8 \%$ to $14 \%$ for the highest risk banks.

- Conventional banks must split out their Islamic banking units by 2023.

- Islamic banks must provide the ratios, based upon an analysis of a customer's revenue and cash-flows, of sharia'h compliant profit-sharing

In 2014, a memorandum of understanding was signed between the 0JK and the National Shariah Board of Indonesian Ulama Council (DSN-MUI), which aims to support the Islamic banking sector. The DSN-MUI will issue fatwas (Islamic legal opinion) and oversee the implementation of sharia'h compliant financing in Indonesia. This centralised approach to shariah compliance differs from the Gulf States', whereby banks each have their own Sharia'h boards to determine compliance of Islamic banking products.

Regulatory framework is among challenges in Islamic banking development in Indonesia because it is not yet optimal, therefore one of 7 Policy Direction Roadmap of Indonesian Islamic Banking 2015-2019 is to strengthen and harmonize its regulations and supervision. The effort to it is given priority by focusing on improvement of the quality of regulation and supervision of Islamic banking, such as:

- improving the institutional regulations and policies related to Financing to Value (FTV)

- guidelines of the resilience of Islamic banks stress test and taxonomic system of regulation related to Islamic banking. ${ }^{16}$

\section{Philippines}

At present, there is only one Islamic bank in the Philippines, the Al-Amanah Islamic Investment Bank of the Philippines. Al-Amanah Bank was established in 1973. While it has been over four decades since the creation of the first Islamic Bank, Islamic banking itself has not grown in large part because of legal constraints. The Al-Amanah Charter created the Bank but not a framework for Islamic banking per se. No such enabling law has so far been passed. In fact, the General Banking Law of 2000 defines Islamic bank as specifically pertaining to Al-Amanah Bank only. The GBL does not provide for the creation of other Islamic banks. If we are to create a truly responsive system of Islamic banks, from a BSP standpoint, certain principles will be important. First, the system must allow for a critical mass of market players under a competitive but well regulated environment. The public must be provided with appropriate choices to suit their risk appetite and financial needs.

Second, appropriate linkages, including inter-bank markets that cater to the unique characteristics of Islamic banking, must be present.

Third, the regulatory and supervisory framework must encourage a level playing field where the Islamic banking system can operate alongside conventional banking. There must be a coherent, consistent and comprehensive set of regulations and standards that would appropriately apply to all banks. In other words, the privileges that are available for conventional banks must also be available to Islamic banks. In the same vein, the prudential requirements that cover conventional banks, must also apply to Islamic banks. The design and

${ }^{16}$ Nelson Tampubolon, "Roadmap of Indonesian Islamic Banking 2015 - 2019”, OJK International Conference on Islamic Finance, Jakarta 12 November 2016. 
implementation of standards, of course, would need to take into account, the particular characteristics of Islamic finance.

Fourth, the regulatory environment must encourage the provision of innovative products and services to address the distinctive needs of Islamic finance. Islamic financial players should be encouraged and not inhibited from introducing Islamic finance products. The regulatory framework could consider the substance [more than the form] of the Islamic products, assess the economic risks involved and use that assessment as basis for regulation. To support this approach, the system must allow for the development of a pool of experts on Islamic finance.

Fifth, the regulatory framework must help build a broader customer and asset base by increasing investor awareness and acceptance, while ensuring consumer protection. While the BSP would like to promote an increase in the number of Islamic banks that operate alongside conventional banks, the BSP is also looking at an "open approach" whereby conventional banks can operate Islamic banking windows, if they so desire, as long as the principles outlined just now are followed. Fortunately, there is growing literature on how these principles can be realized. We can learn from the research and expertise of the Islamic Financial Services Board, of which the BSP is an associate member, other international organizations and friendly governments which have signified interest in supporting BSP in this initiative, as well as from the rich experiences of outstanding practitioners of Islamic banking. To achieve all these objectives, the BSP intends to work towards attaining a suitable legal framework for Islamic banking in the Philippines. We are currently in the very early stages of drafting a general law for the creation and regulation of Islamic banks. Consistent with this, we have included in our list of proposed amendments to our charter, a provision that will enable the BSP to develop regulations for the extension of financial facilities to Islamic banks. ${ }^{17}$

\section{Malaysia}

Today, the Financial Services Act 2013 (FSA) and the Islamic Financial Services Act 2013 (IFSA) are the most significant pieces of legislation to impact the Malaysian financial services industry. Both legislations have been received Royal Assent and gazetted since March 2013. They came into force in the end of June 2013. The FSA consolidates and repeals the Banking and Financial Institutions Act 1989, the Payment Systems Act 2003, the Insurance Act 1996 and the Exchange Control Act 1953 while the IFSA consolidates and repeals the Islamic Banking Act 1983 and the Takaful Act 1984.

Both Acts provide the regulation and supervision of financial institutions, payment systems and other relevant entities, as well as oversight of the money market and the foreign exchange market. Their principal regulatory objective is to promote financial stability by fostering the safety and soundness of financial institutions, the integrity of the money market and foreign exchange market, business conduct of financial institutions, and consumer protection. ${ }^{18}$

As for IFSA 2013, apart from the principal objective of the IFSA discussed above, the IFSA also aims to promote compliance with Shariah principles. To achieve this, it entrenches BNM's role as Shariah regulator, imposes stringent requirements on Shariah governance mechanisms and

\footnotetext{
17 Amando M Tetangco, Jr: Islamic banking and finance in the Philippines - opportunities and challenges Speech by Mr Amando M Tetangco, Jr, Governor of Bangko Sentral ng Pilipinas (BSP, the central bank of the Philippines), at the Islamic Banking and Finance Workshop, Bangko Sentral ng Pilipinas, Manila, 11 March 2014.

18 See: Wan Abdul Rahim Kamil, "Malaysia: World's Islamic Finance Marketplace" in The Islamic Finance Handbook: A Practitioner's Guide to the Global Markets. (Singapore: John Wiley \& Sons Singapore Pte. Ltd, 2014)
} 
caters to the specificities of Islamic financial products and operations which are based upon various types of Shariah contracts.

The IFSA intends to strengthen the foundations for end-to-end Shariah governance and compliance, support the effective application of Islamic contracts in the offering of Islamic financial products and services, from entering into a contract to the resolution of a failed Islamic financial institution, and align legal and regulatory principles with Shariah precepts and promote greater legal and operational certainty.

The main distinction between the FSA and the IFSA lies in the IFSA's extensive requirements on Shariah governance and ensuring Shariah compliance. The IFSA statutorily enforces management of Shariah non-compliance risk and requires Islamic financial institutions to ensure that their aims, operations, business, affairs and activities are in compliance with Shariah principles at all times. Specifically, the IFSA:

i. entrenches the role of BNM as Shariah regulator;

ii. embeds Shariah principles and BNM Shariah Advisory Council (SAC) rulings;

iii. strengthens Shariah governance and compliance requirements;

iv. makes it an offence for IFIs to carry on Shariah non-compliant activities and imposes heavy penalties in relation to Shariah compliance matters; and

v. gives BNM wide powers to assess, intervene, direct and penalise IFIs in relation to offences and breach of IFSA provisions.

IFSA 2013 is an evolution rather than a revolution of the financial regulatory system in Malaysia as it marks a gradual shift away from the laissez-faire and self-regulatory approach of the previous regime towards one of increased regulation and corporate accountability. ${ }^{19}$

The new IFSA 2013 contains 291 sections which covers almost every aspect of the Islamic financial system, including the establishment of an IFI, its winding up and the enforcement framework for any offence under such law. The IFSA has provided the BNM with statutory duties to foster fair, responsible and professional business conduct amongst financial service providers. IFIs have been imposed with two statutory duties, namely compliance and reporting. The IFSA is expected to promote a robust financial consumer protection regime particularly in respect to unfair and deceptive business conduct and disclosure obligations, and provide clear demarcation between conventional and Islamic finance. On top of the IFSA, the BNM has issued four new guidelines to further improve the practice of Islamic finance, namely:

- Capital Adequacy Framework for Islamic Banks (Risk- Weighted Assets), effective as of 1st January 2013;

- Capital Adequacy Framework for Islamic Banks (Capital Components), effective as of 1st January 2013;

- Financial Reporting for Islamic Banking and Islamic Financial Institutions, effective as of 28 June 2013; and

- Guidelines on Ibra (Rebate) for Sale-Based Financing, effective as of 4th February $2013 .^{20}$

\section{Singapore}

According to Monetary Authority of Singapore, ${ }^{21}$ Islamic banking and finance has been offered in Singapore since the 1990s. In recent years, the pace of development has gathered

\footnotetext{
${ }^{19}$ See: Amy Tan Ai Fen, “Malaysia's new financial services regulatory framework," in Financier, July 2013.

20 See: http://isfire.net/the-state-of-islamic-finance-in-malaysia-and-indonesia/
} 
momentum as more institutions offering Islamic financial services entered the market and introduced a wider range of Islamic products and services. The sector has witnessed a number of new and innovative initiatives.

Singapore aims to promote Islamic finance by leveraging on its existing strengths in banking and finance, insurance, asset management, capital market services and risk management. It seeks to provide a favorable operating environment conducive to financial institutions offering a full suite of products and services that includes Islamic finance.

The MAS' regulatory approach is to accommodate Islamic banking products within its existing regulatory framework and to level the playing field by ensuring the neutrality of MAS' rules where Islamic financing is similar to conventional financing in economic substance and risks. Where there are specific risks or impediments, MAS will refine its rules to address these specific areas. MAS introduced banking regulations for the more common Islamic structures including Murabahah financing, Murabahah interbank placement, Ijarah Wa Iqtina, diminishing Musharakah and spot Murabahah. MAS also issued its consolidated "Guidelines on the Application of Banking Regulations to Islamic Banking" covering MAS' general approach to the regulation of Islamic banking, and giving guidance on the admission framework for Islamic financial services and the regulatory and capital treatment for Islamic products. Taken together, these regulations and guidelines provide greater clarity and certainty to Islamic financial services. ${ }^{22}$

Working closely with the Ministry of Finance and Inland Revenue Authority of Singapore, MAS seeks to ensure that Shariah compliant products are not disadvantaged in respect of conventional products in terms of taxes. In addition, to help offset the higher start up costs and facilitate the growth of Islamic finance, a 5\% concessionary tax rate has been introduced for qualifying Shariah compliant lending, fund management, Takaful and re-Takaful activities.

Pursuant to the Banking Regulations (regulations 4A, 22, 23, 23A, 23B, 23C and 23E of the Banking Regulations), banks in Singapore may carry on and offer financing based on Islamic concepts of murabaha, ijara wa iqtina, diminishing musharaka and istisna. In 2010, the MAS issued its comprehensive 'Guidelines on the Application of Banking Regulations to Islamic Banking' which aims to provide banks with guidance on the regulation of Islamic banking in Singapore. ${ }^{23}$

Islamic financial institutions in Singapore are subject to the same legislation under the country's Banking Act as conventional institutions, with capital adequacies and requirements applicable to Islamic banking products in same way as conventional ones. MAS states that the regulatory approach is focused on addressing the risks to the soundness of the country's financial institutions, with reviews in place of regulatory and tax treatment to expedite the issuance of Islamic financial instruments. In 2013, the government allowed the five-year tax window introduced in 2008 on specific Islamic finance instruments to lapse, although the tax treatment for Islamic instruments remains on par with conventional equivalents.

\footnotetext{
21 MAS Press Release

22 See: Lee Ka Sing and Ian Yeo Tian Chiang, "Singapore: An International Hypermarket of Financial Products" in The Islamic Finance Handbook: A Practitioner's Guide to the Global Markets. (Singapore: John Wiley \& Sons Singapore Pte. Ltd, 2014)

${ }^{23}$ http://www.singaporelaw.sg/sglaw/laws-of-singapore/commercial-law/chapter-22
} 
In terms of positioning within the Islamic finance space, Singapore is in competition with jurisdictions such as Luxembourg and the Cayman Islands, which have established themselves as fund domiciles. In October 2013, Singapore signed an MoU with Malaysia and Thailand to develop the ASEAN CIS Framework enabling a cross-border offering of collective investment schemes (CIS). The framework was introduced and made operational in August this year, allowing investors to place funds and issuers to raise capital in any participating country without restriction. Singapore also signed up to an agreement with Australia, Korea and New Zealand in September last year which established the Asia Region Funds Passport (ARFP) to facilitate the distribution of CIS funds across the region, with both schemes providing a wider scope for Islamic investment through fund managers in Singapore.

As a financial center, Singapore is showing a growing appeal for Islamic finance, being a destination for Sukuk roadshows by issuers including Emaar Malls Group, Damac Real Estate and Turkiye Finans. The country has 15 banks off ering Shariah compliant banking options and Islamic wealth management is a growing sector. According to industry experts, Islamic assets under management in Singapore are worth approximately US $\$ 4.37$ billion, with over a third of those held by the 15 banks offering Shariah company banking options. Despite the launch of three new Shariah compliant retail funds in 2013 by Franklin Templeton Investments, there are still fewer than 20 Shariah compliant funds in available in Singapore, providing an incentive for the use if the country's new passporting schemes by both investors and fund managers. ${ }^{24}$

Singapore's approach differs from neighbouring Malaysia in that it applies non-preferential treatment to create a level-playing field for both conventional and Islamic finance rather than providing tax advantages as practiced by the latter. Islamic finance and banking are governed under the same regulation, the Banking Act, which treats Shariah compliant finance within a secular legal structure, with no reference to Arabic names.

Nonetheless, like many other jurisdictions attempting to kickstart their Islamic finance industry, Singapore did make initial concessions to give the sector an advantage in its vastly conventional landscape. Several regulations were introduced between 2005 and 2009 legislating Shariah banking and financing instruments as well as amendments to tax regulations which removed additional tax obligations arising from the asset-based nature of Shariah transactions. In 2013 however, the central bank - Monetary Authority of Singapore (MAS) - allowed two Islamic finance tax incentives (rolled out in 2008) to expire; this led to doubts on MAS's commitment to Islamic finance and banking. Yet despite so, the regulator has consistently reaffirmed its Islamic finance dedication. On the 8th April 2015, a conditional provision for the remission of stamp duty to Islamic financial contracts was made via the Stamp Duties (Islamic Finance Arrangements) (Remission) Rules 2015. ${ }^{25}$

\section{Thailand}

Thailand has every intention to develop an Islamic banking and finance system. Thailand is fortunate to have good friends in the international banking community with the capability and interest in cooperating with it. But Thailand also has its own knowledge of Islamic finance. The Ministry of Finance has teams working on issues of Islamic finance in the Fiscal Policy Office

\footnotetext{
${ }^{24}$ http://www.eurekahedge.com/NewsAndEvents/News/1267/Islamic_Finance_News_Singapore_Opportunities_f or_Islamic_Finance

25 http://www.eurekahedge.com/newsandevents/News/1487/Islamic-Finance-News-Singapore-Too-Little-TooLate
} 
and the Public Debt Management Office, as well as at the Islamic Bank of Thailand. The Bank of Thailand is also actively studying the regulatory aspects of Islamic finance.

Hence, it is not a question of launching Islamic finance in Thailand but rather development of greater sophistication. It needs to train bankers, regulatory supervisors and, in particular, compliance and audit officials in these new skills. ${ }^{26}$

Nevertheless, there are many challenges facing Thailand, and indeed any country, in gaining access to this massive funding base. Five are particularly important:

- The legal and regulatory framework.

- Financial reporting and accounting systems.

- Shariah compliance.

- Availability of education and skills.

- Development of secondary markets.

On the legal and regulatory framework, Thailand recognizes that it is necessary to adapt tax, mortgage and financial institution regulations to accommodate Islamic finance. Thanks to the initiatives of the then Chancellor of the Exchequer Gordon Brown, Britain was able to resolve these issues. As a result, an active, even world leading, Islamic finance market was developed. Malaysia and now Indonesia have within ASEAN also achieved impressive results. Thailand has to study their experiences, both from an institutional viewpoint as well as in terms of tax, mortgage and other specific transaction issues. ${ }^{27}$

According to Aamir Shamim, Senior Vice President - Treasury and Investments at the Islamic Bank of Thailand, that the interest of the international Islamic finance market is not on Thailand. Among the reasons is the Thai government is not behind comprehensive regulations for Islamic finance, and the current regulations do not even allow the state-owned Islamic bank to invest abroad which is heavily limiting its scope. There are currently just three funds in Thailand that are Shariah-compliant and where it can invest. ${ }^{28}$

Another key milestone for Islamic banking in Thailand was the enactment of the Islamic Bank of Thailand Act 2002. This law paved the way for the establishment of the first full-pledge Islamic bank, Islamic Bank of Thailand in 2003. This bank, which is located in Bangkok plans to open branches in Yala, Pattani, Narathiwat and Songkla. ${ }^{29}$

\section{ASEAN Economic Community (AEC)}

The Association of Southeast Asian Nations (ASEAN), now in its late-forties, was created to address mainly political and security issues. Using flexibility and consensus - the ASEAN Way - it helped move the region from conflict to cooperation. Over time, the economy has taken center stage and today the association has reached a critical juncture. In 2015, its members will

\footnotetext{
26 See: S. M. Aamir Shamim, “Thailand: The Uncharted Horizon” in The Islamic Finance Handbook: A Practitioner's Guide to the Global Markets. (Singapore: John Wiley \& Sons Singapore Pte. Ltd, 2014)

27 Sathit Limpongpan, "Islamic Finance for Thailand: Opportunities and Challenges", https://islamicfinanceupdates.wordpress.com/2008/07/11/islamic-finance-for-thailand-opportunities-andchallenges/

${ }^{28}$ Arno Maierbrugger, "Thailand's struggle with Islamic finance”, http://investvine.com/thailands-struggle-withislamic-finance/, Dec 12, 2013.

${ }^{29}$ Sudin Haron \& KuMajdi Yamirudeng, "Islamic Banking in Thailand: Prospects and Challenges", International Journal of Islamic Financial Services Vol. 5 No.2.
} 
be launching the ASEAN Economic Community (AEC). This initiative, which is part of a broader "ASEAN Community" including political-security and socio-cultural pillars, will be taking shape just as the center of global economic gravity is shifting toward Asia. ${ }^{30}$

While the AEC is a milestone in ASEAN's journey toward closer integration - and in maintaining its centrality in Asia's architecture for cooperation - it alone is insufficient to retain relevance in an increasingly multipolar global landscape.

To strengthen their competitiveness and role as a hub of Asia's dynamism, ASEAN countries must also introduce deep structural reforms nationally. A proper combination of domestic reforms and initiatives for closer integration that complement and reinforce one another are needed to promote the region's equitable and inclusive development, strengthen its macroeconomic stability, and protect the environment. ASEAN countries must build their unique brand of integration - to close development gaps and maintain identity. ${ }^{31}$

Signed by the ASEAN Leaders at the $13^{\text {th }}$ ASEAN Summit on November 20,2007 , the ASEAN Economic Community (AEC) Blueprint lays the foundation for realising the goal of ASEAN as an integrated economic region by 2015 . The AEC is characterised by four pillars: single market and production base, highly competitive economic region, a region of equitable economic development, and a region that is fully integrated with the global economy. In each of the four pillars are the various measures and initiatives that are being implemented to achieve the goals of the AEC. ${ }^{32}$

From the official report of May 2014 by the ASEAN, entitled "Thinking Globally, Prospering Regionally - ASEAN Economic Community 2015", the following table summarizes its very positive economic and demographic evolution between 1990, 2000 and 2012.

ASEAN countries form a market of over 600 million consumers and combined GDP of almost US\$3 trillion, with a vibrant and growing economy that presents fantastic economic perspectives for the future of ASEAN.

\section{Principles of the ASEAN Economic Community - AEC}

ASEAN countries form a market of over 600 million consumers and combined GDP of almost US\$3 trillion, with a vibrant and growing economy that presents fantastic economic perspectives for the future of ASEAN.

ASEAN leaders have now embarked the Southeast Asian association to the next step of economic development, which will also ultimately bring the Southeast Asian peoples closer. They have engaged since 2007 towards the integration of ASEAN into an ASEAN Economic community based on 4 economic pillars:

\footnotetext{
${ }^{30}$ Haqqi, Abdurrahman Raden Aji. (2015). "Islamic Financial Institution in ASEAN Economic Community 2015: Prospect and Challenges", International Conference on Islamic Economics and Financial Inclusion, Universitas Muhammadiyah Yogyakarta (UMY), 23-24 April 2015, Yogyakarta, Indonesia.

${ }^{31}$ See: Asian Development Bank Institute. (2014). ASEAN 2030: Toward a Borderless Economic Community. (Japan: IDBI), p. xxi.

32 ASEAN Secretariat. (2012). ASEAN Economic Community: Scorecard. (Jakarta: ASEAN Secretariat), p. 1.
} 


\section{4 pillars of the ASEAN Economic Community}

- Single Market and Production Base

- Competitive Economic Region

- Equitable Economic Development: to receive the benefits of th AEC, the people and businesses of ASEAN must be engaged into the integration process of the AEC

- ASEAN's integration into the globalized economy

Through the implementation of these 4 pillars for economic integration, stability, competitiveness and dynamism, ASEAN is bound to realize the principles of an Economic Community, inspired by the model of the European Union.

A Uniting Force in the Industry of the Region

Components of sound \& robust regulatory framework preserve financial stability and public confidence to Islamic financial institutions in ASEAN. ${ }^{33}$

1. Shariah \& Corporate Governance

- Board \& senior management oversight

- Governance principles peculiar to Islamic banking

2. Risk Management

- Risk shared between bank and depositors (profit sharing)

- Transparency and financial disclosure

- Unique risks e.g. Shariah risk, rate of return risk, displaced commercial risk \& equity investment risk

3. Capital Adequacy Standard

- Subject to capital adequacy framework based on IFSB

- Risk profiles \& exposures determined based on underlying Shariah contracts

4. Firewalls for Islamic window operation

- Segregation of funds

- Separate accounting, clearing and settlement system

- Separate prudential requirements - notional capital, liquidity, single customer limit

5. Consumer protection \& fair dealing

- Rate of return framework

- Islamic deposit insurance

- Market conduct

6. Other Prudential regulation

- Financial Disclosure (GP8-i)

- Exposures to related party

- Single customer limit

\footnotetext{
${ }^{33}$ Overview of the Regulatory Framework Governing the Islamic Banking and Finance Operations in Malaysia

- Central Bank's Perspective, European Forum Of Islamic Finance Milan, Italy 12 May 2009.
} 
- Investment limits

Principles of Regulatory Framework that must be adopted by Islamic financial institutions in ASEAN within the scope of AEC objectives are:

1. Efficiency Related

- Promote competition amongst market participants

- Secure competition neutrality between actual or potential suppliers of financial services

- No party would enjoy competitive advantage as a result of regulation

- Creation of "level playing field"

2. Stability Related

- Promotion of financial system stability \& appropriate degree of safety and soundness through:

- Incentives for proper assessment \& management of risk

- Prescription of regulatory requirements

- Willingness of regulator to take timely action to redress developments threatening existing \& future solvency of IFIs

3. Conflict - Concilatory

- Some objectives \& principles of regulation may be in conflict with one another

○ Must assess priorities \& tradeoffs

- Pursuing target-instrument approach:

- Coordinating combination of instruments to achieve desired targets, whilst offsetting potentially negative effects

\section{CONCLUSION}

To conclude, in Brunei Darussalam, Islamic finance can be a solution to support economic growth and promote long-lasting financial stability. Insya-Allah, with concerted efforts among standard setting bodies, central bankers, regulators, Islamic scholars, and financial industry, we can face the hurdles in developing Islamic finance so that many more people could benefit from the magnificent values of Islam.

In Indonesia, in line with the concrete efforts in developing Islamic banking in Indonesia, Bank Indonesia has formulated a Grand Strategy of Islamic Banking Market Development, as a comprehensive strategy of market development covering strategic aspects for the leading Islamic banking industry in ASEAN, creating the new image of inclusive and universal Islamic banking, mapping a more accurate market segment, developing more various products, improving services as well as adopting new communication strategy of Islamic banking by positioning it as a beyond banking position. (Islamic banking is more than just a bank).

In Thailand, the key milestone to the development of an Islamic banking system in Thailand was the introduction of an 'Islamic window' concept by the Government Savings Bank in 1998, followed by the Bank for Agriculture and Agricultural Cooperatives in 1999. The introduction of 'Islamic Branch' by Krung Thai Bank in 2001 and the establishment of the Islamic Bank of Thailand in 2003 paved the way for a vibrant Islamic banking system in the country. Appropriate rules and regulations must be introduced to protect both banks and customers.

In the Philippines, although the proposed legislation is a crucial step in promoting Islamic finance, and could help to address the lack of financial services in predominantly Muslim 
provinces, market adoption will not be speedy-most of the region's savers and borrowers are unfamiliar with sharia-compliant financial products and services. Still, regulations that promote Islamic finance are a step in the right direction.

In Malaysia, the existing regulatory framework of Shari'ah governance system needs further enhancement and improvement in order to reinforce the development and growing of Islamic finance industry. This brings into focus the measures and efforts that need to be taken to strengthen the IFIs through enhancing the Shari'ah governance framework. It is a strong belief that some common legal elements that underlying and promoting good governance and best practices are fundamentally to be drawn to facilitate the creation and optimize a healthy and viable environment for Shari'ah governance system without impeding further growth of the industry.

In Singapore, Islamic banking and financial institutions must ensure that products and services comply with Islamic laws before and after launch to avoid disputes. An effective governance framework such as this should be done by developing greater knowledge and expertise. Universities and higher education institutions in collaboration with market players are encouraged to offer courses or training programmes, which will provide the necessary knowledge, expertise and experience for the industry. It is expected to almost double by 2018 to bridge the demand for Islamic finance and to support the mobilisation of funds in South-east Asia. This will lead to the issue "of product innovation to preserve and grow the wealth of the Asian and ASEAN population".

\section{BIBLIOGRAPHY}

Abdul 'Ali, Muhd Jamil Abas bin, Swee, Tan Thiam \& Chin, Lee Yun. (2014). "Brunei: Islamic Banking and Finanace" in The Islamic Finance Handbook: A Practitioner's Guide to the Global Markets. (Singapore: John Wiley \& Sons Singapore Pte. Ltd, 2014)

Adil Hussain and Neil Williams, "Islamic Finance in Indonesia”, Clyde and Co, June 15, 2016. See also: http://www.islamicfinancenews.com/newsletter-issue/volume11issue10

Alejandro López Mejía, Suliman Aljabrin, Rachid Awad, Mohamed Norat, and Inwon Song, "Regulation and Supervision of Islamic Banks", IMF Working Paper No WP/14/219, (Washington: International Monetary Fund, 2014.

Amando M Tetangco, Jr: Islamic banking and finance in the Philippines - opportunities and challenges Speech by Mr Amando M Tetangco, Jr, Governor of Bangko Sentral ng Pilipinas (BSP, the central bank of the Philippines), at the Islamic Banking and Finance Workshop, Bangko Sentral ng Pilipinas, Manila, 11 March 2014.

Amy Tan Ai Fen, “Malaysia's new financial services regulatory framework," in Financier, July 2013.

Arno Maierbrugger, “Thailand's struggle with Islamic finance”, http://investvine.com/thailands-struggle-withislamic-finance/, Dec 12, 2013.

Awang Yusof bin Haji Abd Rahman, "Islamic Finance - Steps for a Better Tomorrow", International Finance and Banking Society (IFABS) 2016 Brunei Conference, 16 August 2016, Brunei Darussalam.

ASEAN Secretariat. ASEAN Economic Community: Scorecard. Jakarta: ASEAN Secretariat, 2012.

Asian Development Bank Institute. ASEAN 2030: Toward a Borderless Economic Community. (Japan: IDBI, 2014).

Dr. Tariq Hassan, “Islamic Banking: The Need for Uniform Regulation”, Journal of Islamic Banking and Finance, Vol: 8, Issue:2, April-June 1991, 15-30.

Haqqi, Abdurrahman Raden Aji. (2015). "Islamic Financial Institution in ASEAN Economic Community 2015: Prospect and Challenges”, International Conference on Islamic Economics and Financial Inclusion, Universitas Muhammadiyah Yogyakarta (UMY), 23-24 April 2015, Yogyakarta, Indonesia.

. (2016). "Regulatory Regime in Enhancing the Implementation of Islamic Economics Relating Financial Sectors in Brunei Darussalam", paper presented at $4^{\text {th }}$ ASEAN International Conference on Islamic 
Finance (4th AICIF), IIUM Institute of Islamic Banking and Finance, 6-8 December 2016, Equatorial Hotel, Melaka, Malaysia.

http://isfire.net/the-state-of-islamic-finance-in-malaysia-and-indonesia/

http://isfire.net/the-state-of-islamic-finance-in-malaysia-and-indonesia/

http://www.singaporelaw.sg/sglaw/laws-of-singapore/commercial-law/chapter-22

http://www.eurekahedge.com/NewsAndEvents/News/1267/Islamic_Finance_News_Singapore_Opportunities_fo r_Islamic_Finance

http://www.eurekahedge.com/newsandevents/News/1487/Islamic-Finance-News-Singapore-Too-Little-TooLate

Islamic Financial Service Board. (2015). Core Principles For Islamic Finance Regulation (BANKING SEGMENT)(CPIFR, Kuala Lumpur: IFSB.

Lee Ka Sing and Ian Yeo Tian Chiang, "Singapore: An International Hypermarket of Financial Products" in The Islamic Finance Handbook: A Practitioner's Guide to the Global Markets. (Singapore: John Wiley \& Sons Singapore Pte. Ltd, 2014)

Nelson Tampubolon, “Roadmap of Indonesian Islamic Banking 2015 - 2019”, OJK International Conference on Islamic Finance, Jakarta 12 November 2016.

Overview of the Regulatory Framework Governing the Islamic Banking and Finance Operations in Malaysia Central Bank's Perspective, European Forum Of Islamic Finance Milan, Italy 12 May 2009.

Rifki Ismal, "Indonesia: The Resilience and Prospects of Islamic Banking” in The Islamic Finance Handbook: A Practitioner's Guide to the Global Markets. (Singapore: John Wiley \& Sons Singapore Pte. Ltd, 2014)

Sathit Limpongpan, "Islamic Finance for Thailand: Opportunities and Challenges", https://islamicfinanceupdates.wordpress.com/2008/07/11/islamic-finance-for-thailand-opportunities-andchallenges/

S. M. Aamir Shamim, “Thailand: The Uncharted Horizon” in The Islamic Finance Handbook: A Practitioner's Guide to the Global Markets. (Singapore: John Wiley \& Sons Singapore Pte. Ltd, 2014)

Song, Inwon and Carel Oosthuizen, 2014, "Islamic Banking Regulation and Supervision - Survey Results and Challenges," IMF Working paper No. 14/220, (Washington: International Monetary Fund).

Sudin Haron \& KuMajdi Yamirudeng, "Islamic Banking in Thailand: Prospects and Challenges”, International Journal of Islamic Financial Services Vol. 5 No.2.

The Islamic Finance Handbook: A Practitioner's Guide to the Global Markets. Singapore: John Wiley \& Sons Singapore Pte. Ltd., 2014.

Wan Abdul Rahim Kamil, "Malaysia: World's Islamic Finance Marketplace" in The Islamic Finance Handbook: A Practitioner's Guide to the Global Markets. (Singapore: John Wiley \& Sons Singapore Pte. Ltd, 2014) 